\title{
Organisations and institutions working on marine turtles in the Mediterranean: a preliminary overview
}

\author{
by Max Kasparek
}

\begin{abstract}
This paper gives short descriptions of the aims and activities of intergovernmental and non-governmental organisations dealing with research and conservation of marine turtles in the Mediterranean. For governmental organisations, a list of addresses is provided which enables contact to be made with the relevant governmental institutions. The paper is regarded as a first attempt and a starting-point for the compilation of information on Mediterranean turtle-related organisations and institutions, and hopes to stimulate a more comprehensive directory.

Kurzfassung. In dieser Arbeit werden die Ziele und Aktivitäten von zwischenstaatlichen und nicht-staatlichen Organisationen, die sich mit Forschung und Schutz von Meeresschildkröten befassen, zusammengestellt. Für staatliche Organisationen wird eine Adressenliste zur Verfügung gestellt, die es erlaubt, die relevanten Behörden zu kontaktieren. Die Arbeit wird als erster Versuch gesehen, Informationen über Organisationen und Institutionen, die Bezug zu Meeresschildkröten im Mittelmeer haben, bereitzustellen, und ruft dazu auf, eine umfassende Übersicht zu erstellen.
\end{abstract}

Key words. Sea turtle, information management, inter-governmental organisations, nongovernmental organisations, environmental conventions.

\section{Introduction}

This is an attempt to list those organisations and institutions which either deal exclusively with marine turtles, or for which marine turtles are at least a major activity. It was not always easy to select those organisations which fall within this definition, as many governmental and non-governmental organisations deal in one or another with sea turtles, without turtles being a real "major" activity in the overall performance spectrum. The selection of organisations was made carefully but still remains subjective. The focus of the directory is on east Mediterranean organisations. This means that smaller organisations such as some local NGOs have been included only for the eastern Mediterranean. It should be noted that many turtle researchers work at universities, and some of them have set up research teams. However, as these groups are usually very loose organisational forms, they are not listed here.

Some of the organisations and institutions have themselves provided information for this directory, but information for others has had to be compiled from second-hand sources, e.g. from information available through the Internet.

This compilation of organisations and institutions should be treated as a first attempt to give an overview. It lies in the nature of this undertaking that amendments and additions will become necessary. In particular, addresses change frequently. This list should therefore be 
updated at regular intervals, and it should also be expanded to include individual turtle researchers and conservationists, which was not possible at present.

Recently (September 2001), "The Mediterranean Directory of Environmental Organisations" has been published by WWF International (Across the Waters), and has also become available online at $<$ www.atw-wwf.org $>$. Although this is a very useful directory in general, it provides little specific information on sea turtle-related organisations: an online search with the key word "sea/marine turtle" resulted in only three organisations for the entire Mediterranean.

\section{Intergovernmental organisations}

Organisations are listed here which work within the system of intergovernmental organisations. Two of the entries are the secretariats of international environmental conventions, and one is an institution under the umbrella of an intergovernmental organisation, which is as such not an independent intergovernmental body.

Regional Activity Centre for Specially Protected Areas (RAC/SPA): The RAC/SPA was established by the contracting Parties to the Barcelona Convention and its protocols with the aim of assisting Mediterranean countries in the implementation of the Protocol concerning Specially Protected Areas in the Mediterranean. Tunisia has been the host country to the centre since 1985. RAC/SPA's mission is to assist the Parties in establishing and managing specially protected areas, conducting programmes of scientific and technical research, conducting the exchange of scientific and technical information between the Parties, preparing management plans for protected areas and species, developing cooperation programmes among the Parties, and preparing educational materials designed for various groups. In each state party to the Convention, the RAC/SPA has a focal point appointed by the authorities of the country. The national focal point works in liaison with the RAC/SPA on the technical and scientific aspects concerning the implementation of the Protocol. The national focal points for the SPA meet every two years.

The Parties to the Barcelona Convention included in their priority targets for the period 1985-1995 the protection of Mediterranean marine turtles (Genoa Declaration, September 1985). For this purpose they adopted in 1989 the Action Plan for the Conservation of Mediterranean Marine Turtles. Efforts are undertaken to follow-up the Action Plan through initiating and coordinating activities. These include the organisation of surveys and meetings, and the preparation and publication of status reports and manuals. RAC/SPA works closely together with national and pan-Mediterranean organisations.

Address: Regional Activity Centre for Specially Protected Areas, Boulevard de l'Environnement, PB 337, 1080 Tunis Cedex, Tunisia. Tel.: (+216) 1-795 760, Fax (+216) 1- 797 349, E-mail: car-asp@rac-spa.org.tn.

Secretariat of the Bonn Convention on Migratory Species (CMS): Marine turtle activities of the Convention on the Conservation of Migratory Species of Wild Animals (CMS, Bonn Convention) are focused on Asia and the Atlantic, and include a Memorandum of Understanding on "Indian Ocean - South-East Asia Marine Turtles" and on "Sea Turtles of the Atlantic Coast of Africa". In the Mediterranean, the CMS Secretariat is supporting the "First 
Mediterranean Conference on Sea Turtles" in Rome in October 2001 jointly with the Bern Convention and the Barcelona Convention. 11 out of 20 Mediterranean countries are Parties to the Bonn Convention.

Address: UNEP/CMS Secretariat, United Nations Premises in Bonn, Martin-Luther-KingStr. 8, 53175 Bonn, Germany. Tel.: (+49) 228-8152401, Fax (+49) 228-815-2449, E-mail: cms@cms.unep.de.

Secretariat of the Bern Convention: The Convention on the Conservation of European Wildlife and Natural Habitats (Bern Convention) has a strong focus on conserving marine turtles, and the discussions of the Standing Committee meetings have often been dominated by turtle-related issues. Special attention has been paid to the nesting populations in Greece and Turkey. Through the case file system, the Bern Convention follows up several turtle issues in the Mediterranean, and thus monitors efforts made towards the protection of e.g. certain nesting beaches. In addition to the members of the Council of Europe, two Mediterranean North African states, Morocco and Tunisia, are parties to the Convention. The Secretariat of the Bern Convention jointly with RAC/SPA (Barcelona Convention) and CMS (Bonn Convention) organises the "First Mediterranean Conference on Sea Turtles" in Rome in October 2001.

Address: The Council of Europe (Bern Convention), Mr. Eladio Fernandez-Galiano, Nature and Landscape Division, 67075 Strasbourg Cedex, Tel. (+33) 388412259, Fax (+33) 388413751, E-mail: eladio.fernandez-galiano@coe.int.

\section{Governmental organisations}

It is impossible to list here all the governmental organisations which have an involvement in marine turtle issues. In order to provide contact possibilities, the list below is based on the addresses of the Mediterranean National Focal Points of RAC/SPA (see the actual list under $<$ www.rac-spa.org.tn $>$ ) and the delegates to the Standing Committee of the Bern Convention. It is thought that these persons may be the best to help in making contact with other relevant institutions and government officials.

Albania: Mr. Maksim Deliana, Chairman, Committee of Environmental Protection, c/o Ministry of Health \& Environmental Protection, Blvd. "B. Curri", Nø.5 Tirana, Albania. Tel: (+355) 42-65229, (+355) 42-64904, Fax (+355) 42-65229, E-Mail: cep@cep.tirana.al.

Algeria: Mr. Sid Ali Ramdane, Direction Générale de l'Environnement, Secrétariat d'Etat Chargé de l'Environnement auprès du Ministère de l'Intérieur et des Collectives Locales et de l'Environnement, Avenue de l'Indépendance, Palais Mustapha Bacha, Alger, Algeria. Tel. (+213) 2-659158, Fax (+213) 2-664032.

Bosnia and Herzegovina: Mr. Tarik Kupusovic, National Coordinator for the MAP, 1 Stjepana Tomica Str., 71000 Sarajevo, Bosnia and Herzegovina. Tel. (+387) 71-207949, Fax (+387) 71-207949, E-mail: IHGF@utic-net-ba. 
Croatia: Ms. Lidislava Klasic-Stankovic, State Directorate for the Protection of Nature and Environment, Office for Adriatic, Uzarska 2/1, 51000 Rijeka, Croatia. Tel: (+385) 51213499, Fax: (+385) 51-214324.

Cyprus: Mrs. Myroula Hadjichristoforou, Department of Fisheries and Marine Research, Ministry of Agriculture, Natural Resources and Environment, Aeoloy Street Nø13, 1411 Nicosia, Cyprus. Tel.: (+357) 30-3864, Fax (+357) 2-775955. E-mail: Myroulah@hotmail.com.

European Commission: Mr. Christophe Bail, General Directorate XI, European Commission, Rue de la Loi 200, 1049 Bruxelles, Belgium. Tel.: (+32) 2-2954099, Fax (+32) 22991111.

Egypt: Mr. Ibrahim Abdel Galil, Chief Executive Officer, Egyptian Environmental Affairs Agency (EEAA), 30 Mirs Helwan El-Zyrae Rd., 11728 Maadi, Cairo, Egypt. Tel.: (+20) 25256452, -3753441, Fax (+20) 2-5256490.

France: Mr. Dominique Perreau, Ministère d'Affaires Étrangères, Direction Générale des Affaires Européennes et Économiques, Direction des Affaires Économiques et Financières, Sous-Direction de l'Environnement et des Coopérations Sectorielles, 37 Quai d'Orsay 75007 Paris, France. Tel.: (+33) 1.43.17.44.13, Fax (+33) 1-43174599.

Greece: Mrs. Stavroula Spyropoulou and Mrs. Demetra Spala, Nature Management Section, General Directorate for the Environment, Ministry of the Environment, Physical Planning and Public Works, 36 Trikallon Str., 11526 Athens, Greece. Tel.: (+30) 1-6918202, Fax (+30) 1-6918487.

Israel: Mr. Eliezer Frankenberg, Nature and National Parks Protection Authority (NNPPA), Division of Science and Conservation, 78 Yermiyahu St., 94467 Jerusalem, Israel. Tel.: (+972) 2-6232936 or 3-7762002, Fax (+972) 2-6259783, E-mail: eliezer@huji.ac.il.

Italy: Mr. Giulio Relini, Laboratori di Biologia Marina ed Ecologia Animale, Istituto di Zoologia, Universita di Genova, Via Balbi, 516126 Genova, Italy. Tel.: (+39) 10-2477537 or 2099465, Fax (+39) 10-2477537, E-Mail: sibmzool@unig.it.

Lebanon: Ms. Lina Yamout, Ministry of Environment, P.O Box 701091, Antelias, Lebanon. Tel.: (+961) 1-522222, Fax (+961) 1-523160, E-mail 1.yamout@moe.gov.lb.

Libya: Mr. Abdulmaula A. Hamza, Environment General Authority (EGA), Marine Life Protection Unit, P.O. Box 137983, Alfateh University Post, Tripoli, Libyan Arab Jamahiriya. Tel.: (+218) 21-4840043, Fax (+218) 21-4839991, E-mail: ega@egalibya.org.

Malta: Mr. Alfred E. Baldacchino, Principal Environment Officer, Environment Protection Department, Ministry for the Environment, Floriana, Malta. Tel.: (+356) 231557, Fax (+356) 241378, E-mail: lovella@waldonet.net.mt, admin@environment.gov.mt.

Monaco: Mr. Patrick van Klaveren, Conseiller technique du Ministère Plénipotentiaire, Chargé de la coopération internationale pour l'Environnement et de Développement, Relations extérieures, Villa Girasole, 16 bd de Suisse, 98000 Monaco. Tel.: (+377) 93158148, Fax (+377) 92052891.E-Mail:pvk@mcn.mc, pvanklaveren@gouv.mc.

Morocco: Mr. Hannan, Directeur Général des Eaux et Forêts et de la Conservation des Sols, Ministère de l'Agriculture et de la Mise en Valeur Agricole, Rabat, Morroco. Tel.: (+212) 7763015 or 763166, Fax (+212) 7-764446.

Slovenia: Mr. Boris Krizan, Mzvnkd Piran, Trg bratstva 1, 66330 Piran, Slovenia. Tel.: (+386) 66-75676, Fax (+386) 66-73562, E-mail: robert-turk@zvnkdpi.Sigov.mail.Si. 
Spain: Mr Javier Pantoja Trigueros, Coordinator of Marine Conservation Programme, General Directorate of Nature Conservation, Ministry of Environment, Gran Via San Francisco 4, 28005 Madrid, Spain. Tel.: (+34) 91-5975411, Fax (+34) 91-5975566, E-mail: javier.pantoja@gvf.mma.es.

Syria: Mr. Mohamed Alnimeh, Département de Zoologie, Faculté des Sciences, Université de Damas, Damas, Syria. Tel.: (+963) 11-2234309 or 3330510, Fax: (+963) 11-3335645.

Tunisia: Mr. Bechir Ben Mansour, Président Directeur Général, Agence Nationale de Protection de l'Environnement, 12, Rue du Cameroun, 1002 Tunis Belvédère, Tunisia. Tel.: (+216) 1-840563 or 847122, Fax (+216) 1-848069.

Turkey: Ms. Ebru Kamiloğlu, Foreign Relations Department, Ministry of Environment, Eskişehir Yolu 8. km., 06100 Ankara, Turkey. Tel.: (+90) 312-2851705 or 2853197, Fax (+90) 312-2853739.

\section{Pan-Mediterranean non-governmental organisations}

The list covers organisations which operate throughout the entire Mediterranean, and includes MEDSETCON, which intends to become an umbrella organisation for Mediterranean turtle organisations, although is still being set up.

Greenpeace: see under Greenpeace Greece and Greenpeace Italy.

IUCN/Marine Turtle Specialist Group (Mediterranean and North-eastern Atlantic Subgroup): The IUCN's Species Survival Commission (SSC) is one of six volunteer commissions of the IUCN-The World Conservation Union, a union of sovereign states, government agencies, and non-government organizations. The SSC's mission is to conserve biological diversity by developing and executing programmes to study, save, restore, and wisely manage species and their habitats. The Marine Turtle Specialist Group (MTSG) was established in 1966 as a response to a growing recognition of the endangered status of marine turtle populations worldwide. Today it includes about 250 members around the world. Recently, MTSG has developed a regional structure and the Mediterranean Sea was the first Region to be established. The activities of this "Mediterranean and North-eastern Atlantic Subgroup" include the establishment of MedTurtle, an internet list server, which aims at promoting regional collaborative conservation efforts. It is an all-inclusive website open to all, and to date has some 70 subscribing marine turtle workers. - Address: Dimitris Margaritoulis, Regional Vice-Chair for Mediterranean, IUCN's Marine Turtle Specialist Group, P.O. Box 51154, 14510 Kifissia, Greece. Tel.: (+30) 1-6203873, Fax (+30) 1-6203663, Email: margaritoulis@archelon.gr.

Medasset (Mediterranean Association to Save the Sea Turtles): Medasset was founded in 1988, and was established as a Charitable Trust under U.K. law in 1993. The aims of the organisation are to conserve and protect the remaining Mediterranean sea turtle populations and their marine ecosystems, through scientific research programmes, education, political liaison, publicity, campaigns, beach assessments, talks and the media. It has forged links 
with many sea turtle protection organisations around the world. It has surveyed and reported on over 7,500 km. of Mediterranean coastline from Sardinia to Lebanon and from the Ionian Sea to the shores of Egypt and Libya. The organisation has played a significant role in the constitution of the legal framework for the protection of sea turtles in the Mediterranean, especially in Greece. Since 1988, it has been present as an Observer at Bern Convention Meetings (Council of Europe) where it has been fighting to save nesting beaches in Cyprus, Greece and Turkey. Medasset's research projects have been co-funded and supported by a number of national and international bodies including the EC, the British Chelonia Group, the Greek Animal Welfare Fund/UK, Herpetofauna Conservation International/UK, the United Nations Environment Programme (RAC/SPA/MAP), the WWF/UK, etc. Since 1996 EuroTurtle, an interactive educational and scientific website [www.euroturtle.org] has become increasingly popular with students and the public alike, winning several important international awards. - Address: MEDASSET (UK), c/o 24 Park Towers, Brick St, London W1J 7DD. Secretariat: 1c Licavitou St., 10672 Athens, Greece. Tel.: (+30) 1-3613572, Fax: (+30) 1-3613572, E-mail: medasset@hol.gr.

Medsetcon - The Mediterranean Sea Turtle Conservation Network: In 1999 and 2000, representatives and observers from non-governmental organisations, inter-governmental organisations, governmental organisations and universities convened "Consultations to Facilitate the Creation of a Mediterranean Sea Turtle Conservation Network". This consultation was initiated by Medcoast, a network of scientific institutes for contributing "to a better management of the Mediterranean and the Black Sea", and Widecast, the "Wider Caribbean Sea Turtle Conservation Network". The participants agreed "to pursue the feasibility and the creation of a Mediterranean sea turtle conservation network, which has as its goal 'to create an inclusive regional network of sea turtle NGO's, scientists, conservationists, educators, policy-makers and others capable of taking effective, collaborative action to prevent the extinction and promote the recovery of sea turtles in the Mediterranean Region'". The results of a questionnaire showed that there is strong support for the establishment of a Mediterranean turtle network, with emphasis on non-governmental organisations. At present, the Turkish Society for the Protection of Wildlife (DHKD) hosts the secretariat on an interim basis. - Address: Medsetcon, c/o DHKD, Büyük Postane Cad. No. 43-45, Kat 5-6, Bahçekapı, İstanbul, Turkey. Tel.: (+90) 212-5282030, Fax (+90) 212-5282040, E-mail: kelaynak@dhkd.org.

Societas Herpetologica Europea (Conservation Committee): SEH's Conservation Committee is concerned with the conservation of the herpetofauna in all parts of Europe and adjacent regions, and its members also form the European Reptile and Amphibian Specialist Group of the IUCN Species Survival Commission. Both work as appropriate with MEDASSET. SHE Conservation Committee has observer status in the Council of Europe (Standing Committee of the Bern Convention) and there plays an active role in the conservation of Mediterranean turtles. Results of the Conservation Committee's work are published in Amphibia-Reptilia and elsewhere. - Address: SHE, c/o Dr. Keith Corbett (Chairman), Herpetological Conservation Trust, 655a, Christchurch Road, Boscombe, Bournemouth, Dorset BH1 4AP, United Kingdom, Tel: (+44) 1202-391319, Fax (+44) 1202-392785, E-mail: herpconstrust@hcontrst.force9.net or kcorbett@herpconstrust.org.uk.

WWF Mediterranean Programme: Over the years, WWF has dedicated considerable efforts to the conservation of endangered species and habitats throughout the Mediterranean 
region, and sea turtles have been a significant focus of WWF's attention. A number of initiatives currently exist that attempt to conserve marine turtles in the Mediterranean basin. The most significant efforts focus primarily on the major nesting sites in Greece and Turkey (see under national WWF organisations). A three-year project which started in 1994 was aimed at helping to eliminate the serious gaps in the existing knowledge about the ecology of marine turtles at sea. New methods were used through a mix of laboratory and field research, making extensive use of genetic markers and mathematical modelling. Currently WWF is involved together with RAC/SPA, MedWet and IUCN to support the Libyan authorities in carrying out a survey of marine and coastal habitats along the Cyrenaica coast. - Address: WWF Mediterranean Programme Office (WWF MedPO), Paolo Lombardi, Via Garigliano, 57, 00198 Rome, Italy. Tel.: (+39) 6-84497227, Fax (+39) 6-8413866. E-mail: plombardi@wwfmedpo.org.

\section{National and local non-governmental organisations}

Aquarium La Rochelle: The Aquarium of La Rochelle includes a Centre for Sea Turtle Studies, carrying out scientific research on marine turtles, e.g. autopsy of dead turtles. Address: Aquarium La Rochelle, Mr. Pierre Morinière, Port des Minimes, 17002 La Rochelle, Cedex 1, France. E-mail: aquabio@aquarium-larochelle.com. Internet: www.aquarium-larochelle.com.

Aquarium of Naples: see Stazione Zoologica “Anton Dohrn”.

Archelon - Sea Turtle Protection Society of Greece (STPS): The organisation was established in 1983 with the objectives of studying, protecting and managing sea turtle populations and their habitats. Ongoing projects include the study and protection of nesting activity on all major nesting beaches in Greece (Zakynthos, Kyparissia Bay, Lakonikos Bay, Crete) and intensive on-site public awareness programmes in all major nesting areas through information stations, slide shows, beach patrols, safeguarding. Lobbying is done both locally and nationally for sea turtle conservation in Greece. Projects are carried out in cooperation with various Ministries and competent authorities, partly with support from the European Commission. Archelon was instrumental in the establishment of the first National Marine Park for sea turtles in the Mediterranean (Zakynthos). Further activities include the operation of a Sea Turtle Stranding Network nationwide, the operation of a Sea Turtle Rescue Centre at Glyfada, and intensive environmental education programmes. - Address: Archelon, the Sea Turtle Protection Society of Greece, Solomou 57, GR 10432 Athens, Greece. Tel./Fax: (+30) 1-5231342, E-mail: stps@archelon.gr, Internet: www.archelon.gr.

Central Institute for Applied Marine Research (ICRAM): ICRAM is the host institute for the "First Mediterranean Conference on Sea Turtles". - Address: Central Institute for Applied Marine Research (ICRAM), Mrs. Giulia Mo, Via di Casalotti 300, Rome 00166, Italy, Tel. (+39) 6-61570444, Fax (+39) 6-61550581 or 61561906. E-mail: mogiulia@tin.it. Internet: www.icram.org. 
Centro Oceanografico de Málaga: The Centro Oceanografico de Málaga is part of the Instituto Español de Oceanografia (Spanish Institute of Oceanography), a public research organization conducting oceanographic research, advising the Spanish government on its oceanographic and fishing policies, representing Spain in international oceanography and fishing organisations, promoting co-operation in marine research at the regional, national and international levels, and training oceanographers and disseminating oceanographic knowledge. The institute has been working on marine turtles for more than 20 years, mainly on Caretta caretta and Dermochelys coriacea. Work includes study of the effects of fisheries on turtle populations, investigations on migratory patterns, genetic analyses, and a tagging programme. - Address: Centro Oceanografico de Málaga, Instituto Español de Oceanografia, Mr. Juan A. Caminas, Apdo 285, 29640 Fuengirola. Tel. (+34) 952-476955, Fax (+34) 952-463808, E-mail: jacaminas@ma.ieo.es. Internet: www.ieo.es.

Centro Studi Cetacei (CSC): CSC is a non-governmental organisation based at Milano and working at a national level on a census of cetaceans. Since 1998 the CSC also runs a tagging programme for marine turtles in the Mediterranean. - Address: CSC Museo Civico Storia Naturale, Corso Venezia 55, Milano, Italy. Tel.: (+39) 2-781312; Fax: (+39) 2-76022287. Email: centrostudicetacei@libero.it.

Chelon: Chelon is a non-governmental organisation carrying out marine turtle research projects. In the Mediterranean, work has been done in particular in Greece and Turkey. Address: Chelon, Marine Turtle Conservation and Research Program, V.le Val Padana, 134/B, 00141 Roma, Italy; Tel./Fax (+39) 681-25301. E-mail: chelon@tin.it.

Cyprus Conservation Foundation (CCF): The Cyprus Conservation Foundation is a charitable trust incorporated in 1992. The aims are to promote environmental and conservation education and awareness. The CCF has established an Environmental Studies Centre close to the Akamas Peninsula (Kritou Terra). The Foundation runs seminars and courses in all parts of the island for government and private sector decision-makers. Activities include the conservation of Akamas Peninsula (Cyprus) and its marine turtles. The Foundation has taken part as an observer in the relevant Meetings of the Bern Convention. - Address: Cyprus Conservation Foundation, P.O. Box 50257, 3602 Limassol, Cyprus. Tel.: (+357) 5-358632, Fax (+357) 5-352657, E-mail: ccf@cylink.com.cy.

Cyprus Wildlife Society: The Cyprus Wildlife Society has cooperated for many years with the Department of Fisheries and Marine Research in the execution of the Cyprus Turtle Conservation Project. It has also been running every year, since 1989, training courses on turtle conservation techniques and beach management, for RAC/SPA sponsored trainees, at the Turtle Station in the Lara/Toxeftra Turtle Reserve, in cooperation again with the Fisheries Department. Through these courses, many of the Mediterranean scientists now working on turtle conservation have been trained. It was also the main sponsor and publisher of the Manual on Marine Turtle Conservation for the Mediterranean (with RAC/SPA and others). Address: Cyprus Wildlife Society, c/o Andreas Demetropoulos, Eolou Street No 13, 4281 Nicosia 1703, Cyprus. Tel.: (+357) 2-350316, Fax (+357) 2-350316. E-mail: andrecws@logos.cy.net.

Fondazione Cetacea: Fondazione Cetacea is a non-profit organisation that operates in the study and conservation of Cetaceans and, more generally, in safeguarding the sea and its resources. Since its foundation in 1988, Fondazione Cetacea has also dealt with the recovery of sea turtles which strand on the northern Adriatic coast. Fondazione Cetacea has two in- 
stallations available for the treatment and recovery of sea turtles: at Delphinursery Cattolica and at Delphinarium Riccione. - Address: Fondazione Cetacea Onlus, via Milano 63, 47838 Riccione (RN), Italy. Tel. (+39) 541-691557, Fax (+39) 541-606590. E-mail: cetacea@iper.net. Internet: www.fondazionecetacea.org.

Friends of the Environment Association, Alexandria: A small but active organisation, monitoring the slaughter of marine turtles in Alexandria, Egypt, and conducting awareness campaigns on this issue. Most activities are carried out jointly with Medasset. - Address: Friends of the Environment, c/o Dr. Mohamad Nada, Ahmed Shawkey St. 394, Mostafa Kamel, Abrag El Ashrafe, Alexandria, Egypt, Tel.: (+20) 3-5434682-03, E-mail: mohamednada70@hotmail.com.

Greenpeace Greece: Greenpeace Greece has made a great contribution to sea turtle conservation on Zakynthos. - Address: Greenpeace Greece, Zoodochon Pigis 52c, 10681 Athens, Greece. Tel. (+30) 1-3840774, Fax (+30) 1-3804008, E-mail: greenpeace.greece@greenpeace.org.

Greenpeace Italy: Greenpeace Italy has assisted several important activities regarding the interaction between turtles and fisheries all over the Mediterranean. - Address: Greenpeace Italy, Viale Manlio Gelsomini 20, 00153 Rome. Tel. (+39) 06-5729991, Fax (+39) 065783531. E-mail: staff@greenpeace.it.

Hellenic Society for the Protection of Nature: The Hellenic Society for the Protection of Nature was founded in 1951. The activities of the Society are directed towards protection of the natural environment through co-operation with various governmental bodies for the improvement of laws, regulations, etc., and co-operation with other NGO's for the same purpose. Active lobbying for the creation of National Parks. It acts as the official National Agency for the NATUROPA Bureau of the Council of Europe. This organisation was very helpful in the early turtle work in Greece. Now, as an institution for assigning Blue Flags to community beaches, it has developed specific criteria for identifying the compatibility of tourism needs with marine turtle needs. - Address: Hellenic Society for the Protection of Nature 24, Nikis str., 10557 Athens, Greece. Tel. (+30) 1-32 24 944, Fax: (+30) 1-3225285, E-mail: hspn@hol.gr.

Hydrobiological Station of Rhodes: The Station was founded in the period 1934-1936 at the northernmost tip of the island and the town of Rhodes. Today it is a branch of the National Centre for Marine Research (NCMR). It has been rehabilitating injured marine turtles for several years, co-operating with fishermen who bring to the station turtles in need of treatment. Has a specific turtle corner in its museum which thousands of tourists visit during summer. Educational programmes carried out for schoolchildren during winter include marine turtles. - Address: Hydrobiological Station of Rhodes, Cos street, 85100 Rhodes, Greece. Tel. (+30) 241-27308, Fax (+30) 241-78321, E-mail: hsr@rhs.rho.forthnet.gr.

Hydrosphera: The non-governmental association "Hydrosphera" has been working since 1994 on Linosa, a little volcanic island belonging to the Pelagian Islands, in the south of Italy. The work includes field activities on nesting sites (monitoring), tagging, and awareness-building among fishermen. Together with the provincial government of Agrigento (Provincia di Agrigento, Dipartimento Conservazione Natura; CTS), the Department of Animal Biology of Turin University (Dipartimento Biologia Animale, Università di Torino; CNR-IATA) and the administration of the Nature Reserve (Riserva Naturale) "Isola di Lampedusa", Hydrosphera has formed a group which runs a EU-LIFE Project on "Urgent 
measures for the conservation of Caretta caretta on the Pelagian Islands" <www.progettocaretta.it>. - Address: Hydrosphera Association, Via Oslavia 12, 00195 Roma, Italy. E-mail: hydrosphera-wolit@tiscalinet.it.

Institute of Marine Biology of Crete (IMBC): The IMBC was founded in 1987 as an independent research organisation by the then Greek Ministry of Industry, Energy, Research and Technology, under the direct supervision of the General Secretariat for Research and Technology. IMBC has been widely recognised as one of the leading marine research institutes in the Mediterranean. It is equipped with state-of-the-art facilities to carry out its many research programmes in various fields. IMBC undertakes projects on the mapping of turtle nesting areas (including the marine areas in front of them), on marine turtle genetics and on marine turtle fisheries interactions. Some activities have recently received support from the European Commission. - Address: IMBC, P.O. Box 2214, 71003 Iraklio, Crete, Greece. Tel. (+30) 810-346860, Fax (+30) 810-241882, E-mail: imbc@imbc.gr.

Katelios Group for the Research and Protection of Marine and Terrestrial Life: A very active local NGO on the island of Kephalonia. - Address: Katelios Group for the Research and Protection of Marine and Terrestrial Life, Katelios, Kefalonia, Greece. Tel. (+30) 67181009.

Marine Animal Rescue Centre (CRAM): Founded in 1991, CRAM aims at conserving and recovering marine animals. The action lines are focused on three main targets: (1) the rescue, recovery and reintroduction of protected marine animals that are either ill, have been stranded, or have been caught by accidental fishing; (2) the promotion of research on endangered species; (3) the creation of awareness by the public about threatened species. CRAM works closely with the Agriculture Stockbreeding and Fisheries Department of the Catalan Government and has developed a quick-response network to mobilize various groups of volunteers. One of the most important programs of CRAM is the Marine Turtles Rescue Program called "Help them", which started in 1995. Over 400 stranded and/or accidentally captured Loggerhead Turtles have been treated by CRAM. They are often ill, injured, dehydrated and/or undernourished due to a hook being located in their oesophagus or stomach for some time. After treatment, they go through a recovery period on CRAM facilities before being released back into the sea. All turtles are tagged with a subcutaneous Passive Integrated Transponder (PIT) in the nape of the neck. - Address: Camí Ral 239, Premià de Mar (Barcelona), Spain. Tel.: (+34) 7524581, Fax: (+34) 7525710. E-mail: cram@cram.es.

Marine Biology Research Centre Tajura, Libya (MBRC): MBRC was established at Tajura, Tripoli, in 1981. Its objectives include carrying out field studies, research and training activities in the domain of marine biology, establishing classified reference collections of marine and coastal lagoon fauna and flora, and documenting and publishing results of studies/research works. The MBRC Management Committee includes representatives of universities, research institutes and scientific governmental institutions. Sea turtles are one of the research topic at MBRC, and the centre was a partner in the national nesting surveys carried out 1995, 1997 and 1998. - Address: Dr. A. El Hamdi (Director General), Mr. Hisham El Gomati (sea turtle specialist), P.O. Box 80830, Tajura-Tripoli, Libya. Tel. (+21) 821-3690001, Fax (+21) 821-369002, E-mail: drawatig@yahoo.com. Internet: www.ua.es/copemed/en/country/focalpts/libya.

Medasset Greece: This is a sister organisation of Medasset (UK), and provides international secretariat services for the UK organisation. Its Greek language activities have done much 
since its inception as a Somateion (Registered NGO) in 1993 to bring about sea turtle protection legislation in Greece, and the establishment of the Zakynthos National Marine Park that was formalised in Greek Law in December 1999. The organisation's main tasks are in scientific research, the promotion of public awareness, campaigns, media, fundraising and political lobbying. It has given countless talks and lectures as part of its commitment to environmental education. Its base in Athens makes it ideally situated as a centre for sea turtle conservation in the countries of the Central and Eastern Mediterranean. - Address: Medasset Greece, 1c Licavitou St., 10672 Athens, Greece. Tel.: (+30) 1-3613572, Fax: (+30) 1-3613572, E-mail: medasset@hol.gr.

Samandağ Çevre Koruma ve Turizm Derneği: A local non-governmental organisation whose activities include the protection of the Green Turtle nesting beach at Samandağ, Turkey. - Address: Samandağ Çevre Koruma ve Turizm Derneği, Mr. İsmail Zubari, Cumhuriyet Cad., Günay İşhanı No. 7, Samandağ (Hatay). Tel. (+90) 326-5128081, E-mail: scevko@hotmail.com.

Sea Turtle Working Group within the Spanish Society for Cetaceans (GTTM - SEC): This group includes almost all the Spanish experts on marine mammals and sea turtles. SEC is a non-profit organization which involves and coordinates all the work on sea turtles in Spain. - Address: Sea Turtle Working Group (GTTM - SEC), Mr. Julio Valeiras (coordinator), Spain. E-mail: julio.Valeiras@ma.ieo.es, sec@cetaceos.com. Internet: www.cetaceos. com.

Society for the Protection of Sea Turtles in Northern Cyprus: A small group of volunteers, working on the protection of marine turtles in the nesting areas, particularly at Karpaz, Alagadi and in the north-west. Public awareness is an important activity. Much work is done in close cooperation with the Marine Turtle Research Group of the University of Wales Swansea, including the publication of the Newsletter "Turtle News". - Address: Society for the Protection of Sea Turtles in Northern Cyprus, P.K. 42, Girne, Mersin 10, Turkey. Email: celian@iecnc.org.

Stazione Zoologica "Anton Dohrn": The Zoological Station "Anton Dohrn" is an international public research institute for marine biology, and the Aquarium of Naples is an integral part of it. The Aquarium is involved in a conservation and research programme on sea turtles in the Gulf of Naples and the areas nearby (Tyrrhenian Sea), including practical measures for the recovery and release of injured and stranded individuals. Scientific research focuses on biology and physiology, ecology, population dynamics and migration. - Address: Stazione Zoologica “Anton Dohrn", Naples Aquarium, Villa Comunale 1, 80121 Naples, Italy. Tel.: (+39) 81-5833222, Fax: (+39) 81-5833294. E-mail: flegra@alpha.szn.it. Internet: www.szn.it.

Türkiye Doğal Hayatı Koruma Derneği (DHKD): Founded in 1975, The Society for the Conservation of Nature (DHKD), whose goals include encouraging sustainable use of natural resources and increasing public awareness on environmental issues, has been dealing with marine turtle conservation and integrated coastal management since 1988. Several projects were carried out in cooperation with organisations such as WWF, and with funding from sources such as the EU LIFE programme. Major work of DHKD has been carried out for turtle conservation in Dalyan and some of Turkey's seventeen other nesting beaches. Ongoing activities include the "Coastal Zone Management and Marine Turtles in Turkey Project" which include the publication of the bi-monthly bulletin "Kumsal" and the organi- 
zation of training courses and workshops for central and local decision-makers and NGOs, and awareness and monitoring activities at selected nesting sites. The Foundation for the Conservation of Nature, which was founded in 1996, gained the status of a national organisation of WWF (WWF-Turkey) in 2001. - Address: DHKD, Büyük Postane cad. No: 43-45, Kat 5-6, Bahçekap1, İstanbul 34420, Turkey. Tel: (+90) 212-5282030, Fax (+90) 2125282040. E-mail: kelaynak@dhkd.org. Internet: www.dhkd.org.

WWF Greece: WWF Greece is a National Organisation of the WWF international network. WWF Greece's mission is achieved through its conservation field projects and policy work. It has also carried out considerable policy work that has contributed to the improvement of the Greek State's environmental legislation and attitude. Regarding marine turtles, a major effort is the purchase and management of the land surrounding Sekania on Zakynthos Island, the most significant nesting beach of Caretta caretta. WWF Greece has also identified the west coast of Zakynthos as the most significant habitat of the Monk Seal Monachus monachus in the Ionian Sea and through the area's legal protection has promoted an integrated conservation and development project in the region. - Address: WWF Greece, Theodota Nantsou, Conservation Manager, 26 Filellinon Street, 10558 Athens. Tel.: (+30) 1-3314893, Fax: (+30) 1-3247578, E-mail: t.nantsou@wwf.gr.

WWF Turkey: see Türkiye Doğal Hayatı Koruma Derneği (DHKD).

Zakynthian Ecological Movement: This organisation has been very active on the island of Zakynthos for the protection of the Loggerhead Turtle nesting beaches. Main focus is on local, national and international lobbying. - Address: Zakynthian Ecological Movement, attn. Mr. Eleftherios Levantis, c/o European Public Law Centre, Achaiou Str. 16, Athens 10675, Greece. Tel./Fax (+30) 1-6231642, E-mail: elan@hol.gr.

Author's address: Dr. Max Kasparek, Mönchhofstr. 16, 69120 Heidelberg, Germany. - E-mail: Kasparek@t-online.de 